$5-21-2019$

\title{
Exercises in New Creation from Paul to Kierkegaard
}

Colby Dickinson

Loyola University Chicago, cdickinson1@luc.edu

Follow this and additional works at: https://ecommons.luc.edu/theology_facpubs

Part of the Religious Thought, Theology and Philosophy of Religion Commons

\section{Recommended Citation}

Dickinson, Colby. Exercises in New Creation from Paul to Kierkegaard. Reading Religion, , , 2019. Retrieved from Loyola eCommons, Theology: Faculty Publications and Other Works,

This Book Review is brought to you for free and open access by the Faculty Publications and Other Works by Department at Loyola eCommons. It has been accepted for inclusion in Theology: Faculty Publications and Other Works by an authorized administrator of Loyola eCommons. For more information, please contact ecommons@luc.edu.

\section{c) (i) $\ominus$}

This work is licensed under a Creative Commons Attribution-Noncommercial-No Derivative Works 3.0 License. (c) American Academy of Religion, 2019. 


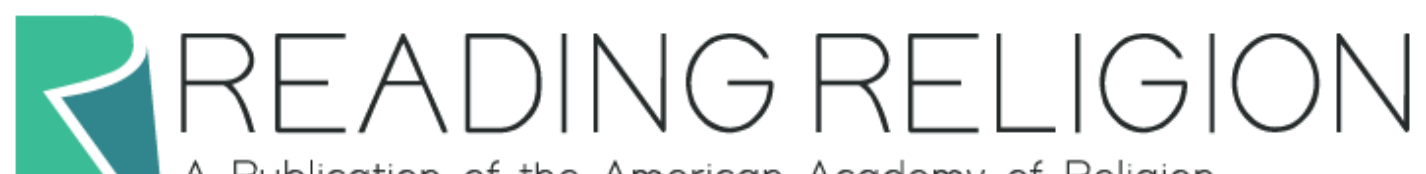

A Publication of the American Academy of Religion

Featured

Reviewed

Reviews Coming Soon

Available for Review

Review Essays

Author Interviews

About

HOME

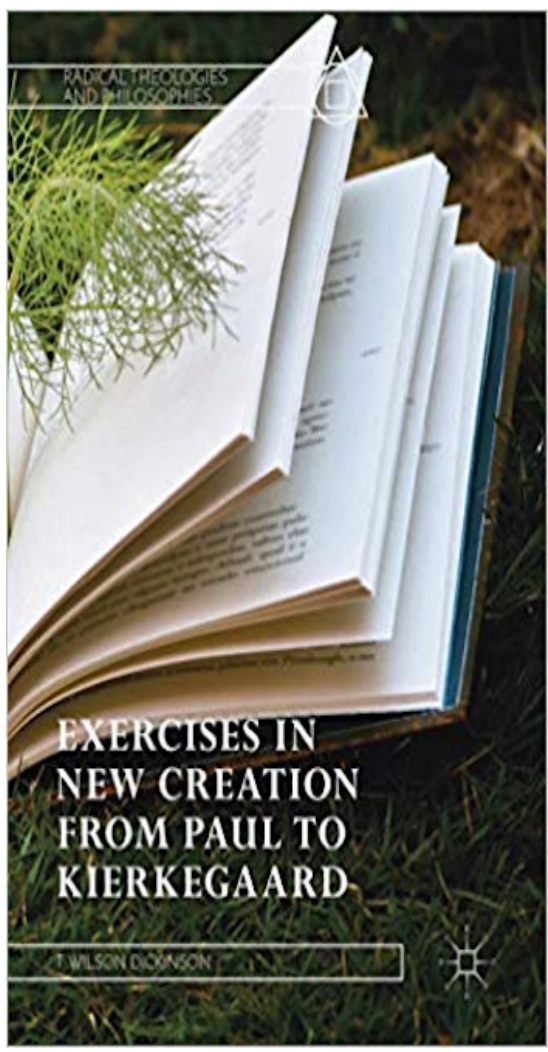

Link to Publisher's Website

Exercises in New Creation from Paul to Kierkegaard

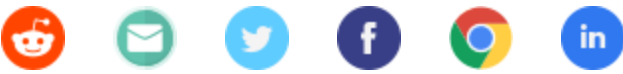


Radical Theologies and Philosophies

London, England: Palgrave Macmillan, October 2018. 276 pages. \$89.99. Hardcover. ISBN 9783319978420.

For other formats: Link to Publisher's Website.

\section{Review}

In Exercises in New Creation from Paul to Kierkegaard, T. Wilson Dickinson has given us a holistic presentation of the wisdom that humanity is capable of exhibiting in its care for the self, the city, and creation as a whole. The fact that humankind has often historically failed in cultivating such wisdom is what makes this book a timely reminder of the significance of looking beyond the "old ways" of doing theology. Utilizing authors who pushed the limits of writing-often merging their personal lives into their theological and philosophical perspectives-and so focusing on Paul, Augustine, Martin Luther, Søren Kierkegaard, and Jacques Derrida, Dickinson shows how each author develops a rigorous and sustained examination of the self in the reading and writing practices they engaged. Indeed, such literary habits open a window for each writer to a care of the self that, in turn, alters humanity's relationships with others, those of the city, and those of creation more broadly. Though Dickinson peers frequently into the privileged, and often idealistic, exercises of reading and writing (a point he gladly acknowledges), there is a profound transformation in relations between humanity and creation that can only take place through the excess of language that uniquely characterizes human existence. If wisdom is truly to be transformative of humanity's affiliation with creation, then turning to literary and pedagogical activities is not a distraction from this task, but a central way to reformulate the human being's understanding of itself and the various orders it creates within this world-most of which having a significant impact upon creation. This focus upon literary exercises as a way to rethink about our connection to creation is, in fact, part of the subtlety of the argument that the book puts forward, and it is one that permeates every page and figure in remarkable ways.

As Dickinson makes clear, an attentiveness to the (Pauline) wisdom of the cross expands knowledge of self, city, and creation. We are thereby presented with a type of wisdom that is not only insurrectionist with regard to established imperial orders, but is also capable of redirecting the attention of humanity toward its part in a larger ecological context. In describing such wisdom, a host of philosophical and theological voices merge in Dickinson's study in order to illuminate a path from the unjust orders of our world-which all-too-frequently result in the marginalization of persons and the destruction of nature-to a messianic vision for a new creation that surpasses even what Paul could have imagined. Though such a new creation is modelled on Pauline thoughts about the "wisdom of the cross" and the new body in Christ that results from its application, it evolves over time-and as we see in the writings of Augustine and Kierkegaard in particular-into alternative perspectives on our creaturely life that stress simplicity and wisdom. It is within these contexts as well that we hear cries for an excessive justice that points directly toward those lives that exceed the boundaries of whatever created order dominates those social and political existences which overshadow the simplicity of creation itself.

There is no doubt that contemporary theology must entirely reformulate its take on creation through renegotiating its association with various ecological issues. It must also account for its past failure to be attentive to the care of creation, as Dickinson deftly and repeatedly illustrates. This is where continental philosophical insight is, at times, brought forth by Dickinson, in order to find-within Pauline theology-an answer to our contemporary environmental crises. Exercises in New Creation is, in my opinion, a worthy companion to all of the philosophical commentary on Pauline thought that has appeared over the past few decades, and one that very much gets to the heart of the theological importance of these otherwise philosophical endeavors. The fact that Dickinson holds his own within such a context, ever mindful of the anthropological conclusions that Pauline thought engenders, while also tasking theological discussion with a complete rethinking of its ecological moorings, is a sign that the subtlety that flows throughout the work is more than mere cleverness. It is the mark of a solid argument that is bound to win over the mind of any who devote themselves to studying its premises.

\section{About the Reviewer(s): \\ Colby Dickinson is Associate Professor of Theology at Loyola University, Chicago.}

Date of Review:

May 21, 2019

About the Author(s)/Editor(s)/Translator(s):

T. Wilson Dickinson teaches Theology and is Director of the Doctor of Ministry and Continuing Education Programs at Lexington Theological Seminary.

\section{Comments}

Reading Religion welcomes comments from AAR members, and you may leave a comment below by logging in with your AAR Member ID and password. Please read our policy on commenting.

\section{Log in}

